\title{
Role of chronic E. coli infection in the process of bladder cancer- an experimental study
}

\author{
Hala El-Mosalamy ${ }^{1 *}$, Tarek M Salman², Abeer M Ashmawey ${ }^{3}$ and Nada Osama ${ }^{4}$
}

\begin{abstract}
Background: Bladder cancer is a common malignancy in Egypt. A history of urinary tract infection can be considered as a risk factor for bladder cancer. Escherichia coli (E. coli) infection is responsible for $70 \%$ of urinary tract infection. This study aimed to evaluate the role of chronic E. coli infection during bladder carcinogenesis. In order to achieve this aim, we investigated the histopathological changes in bladder tissue and measured the level of nuclear factor kappa p65 (NF-kBp65), BCl-2 and interleukin 6 (IL-6) in four groups each consisting of 25 male albino rats except of control group consisting of 20 rats. The first group was normal control group, the second group was infected with E. coli, the third group was administered nitrosamine precursor, and the forth group was infected with $E$. coli and administered nitrosamine precursor.

Results: The histopathological examination revealed that E. coli infected group was able alone to produce some histopathological changes in bladder tissue and that nitrosamine precursor plus $E$. coli group showed highest incidences of urinary bladder lesions than the nitrosamine precursor group. NF-KBp65, Bcl-2 and IL-6 levels were significantly higher in nitrosamine precursor plus E. coli group than the other groups.

Conclusion: These findings suggested that urinary bladder infection by E. coli may play a major additive and synergistic role during bladder carcinogenesis.
\end{abstract}

Keywords: Bladder carcinogenesis, E. coli, NF-kBp65, Bcl-2, IL-6

\section{Background}

Bladder cancer is a common malignancy, worldwide; it is the seventh most prevalent cancer, accounting for $3.2 \%$ of all malignancies [1]. Carcinoma of the bladder is the most prevalent cancer in Egypt. At the national cancer institute, Cairo University, it constitutes $30.3 \%$ of all cancers $[2,3]$. Nitrate contamination of drinking water was reported as a risk of bladder cancer. Nitrates are endogenously reduced to nitrites, which through subsequent nitrosation give rise to highly carcinogenic $\mathrm{N}$ nitroso compounds [4]. Other etiological factors implicated in the development and progression of bladder cancer includes urinary tract infections (UTIs) including bacterial, parasitic, fungal, and viral infections; urinary lithiasis and pelvic radiation [5]. Bacteria are the primary cause of UTIs, with the vast majority (70-80\%) attributed specifically to infection with $E$. coli. A recurring

\footnotetext{
* Correspondence: hala_elmosalamy@yahoo.com

'Biochemistry Department, Faculty of Pharmacy, Ain Shams University, Cairo, Egypt

Full list of author information is available at the end of the article
}

theme in the link between bacterial infection and carcinogenesis is that of chronic inflammation, which is often a common feature of persistent infection [6,7]. One of the key molecules that link chronic inflammation and cancer is represented by the NF-kB family of transcription factors [7]. NF- $k \mathrm{~B}$ activation induces the expression of more than 200 genes which have been shown to suppress apoptosis and induce cellular transformation, proliferation, invasion, metastasis, chemo-resistance, radio-resistance, and/or inflammation [8]. Altered expression of genes involved in suppression of apoptosis (i.e. Bcl-2 family members and inhibitor of apoptosis proteins), a key feature of cancer cells, is often due to deregulated NF- $\mathrm{KB}$ activity. The expressions of numerous cytokines that are growth factors for tumor cells such as interleukin $1 \beta$ (IL-1 $\beta$ ); tumor necrosis factor (TNF); epidermal growth factor (EGF) and IL-6 are also regulated by NF-kB [9]. IL-6 is a major proinflammatory cytokine that participates in inflammationassociated carcinogenesis [10]. Elevated plasma and urine levels of IL- 6 have been demonstrated in cancer

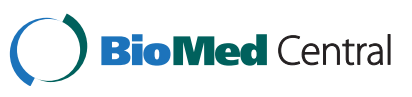


and inflammatory diseases of the urinary tract [11]. This study aimed to evaluate the possible role of $E$. coli infection during bladder carcinogenesis and the changes in NF- $\kappa B$ pathway and its related products.

\section{Results}

All experimental protocols and procedures were approved by the Animal Ethics Committee of Cairo National Cancer Institute.

\section{Histopathological examination}

Bladder histopathological changes are presented in Figure 1. The histopathological examination revealed that E. coli infected group was able alone to produce some histopathological changes in bladder tissue ranging from inflammation to dysplasia and that nitrosamine precursor plus E. coli group showed highest incidences of urinary bladder lesions than the nitrosamine precursor group and E. coli group.

\section{NF-kB p65, Bcl-2 and IL-6 levels}

Levels of NF-kB p65, Bcl-2 and IL-6 are presented in Table 1. As indicated in Table 1, at 3 months interval, the mean \pm SD of NF-kB p65, Bcl-2 and IL-6 levels were significantly higher in the three groups compared with those obtained in the control group $(\mathrm{P}<0.05)$. In addition a significant difference was observed among the three groups, with those of group IV (receiving nitrosamine precursor and infected with E. coli) showing the highest values. Regarding NF- $\mathrm{kB}$ p65 levels, there was a significant increase in group II $(0.92 \pm 0.22 \mathrm{ng} / \mathrm{ml})$, group III $(0.84 \pm 0.17 \mathrm{ng} /$ $\mathrm{ml})$, and group IV $(1.19 \pm 0.19 \mathrm{ng} / \mathrm{ml})$ compared with the control group $(0.57 \pm 0.07 \mathrm{ng} / \mathrm{ml})$. The anti-apoptotic protein; Bcl-2 level was significantly increased in groups II $(354.74 \pm 23.44 \mathrm{U} / \mathrm{ml})$, group III $(331.78 \pm 11.86 \mathrm{U} / \mathrm{ml})$, and group IV $(387.05 \pm 8.40 \mathrm{U} / \mathrm{ml})$ compared with the control group level (309. $14 \pm 14.55 \mathrm{U} / \mathrm{ml}$ ). Finally for IL-6 level there was a significant increase in group II $(19.76 \pm 1.64 \mathrm{pg} /$ $\mathrm{ml})$, group III $(19.21 \pm 1.56 \mathrm{pg} / \mathrm{ml})$, and group IV $(24.80 \pm 2.20 \mathrm{pg} / \mathrm{ml})$ compared with the control group $(14.09 \pm 0.87 \mathrm{pg} / \mathrm{ml})$.

At 6 months interval, the mean \pm SD of NF- $k B$ p 65 , Bcl-2 and IL-6 levels also showed significant increase in the three groups compared with those obtained in the control group. In addition a significant difference was also observed among the three groups, with those of group IV (receiving nitrosamine precursor and infected with E. coli) showing the highest values. Regarding NF$\kappa B$ p65 levels, there was a significant increase in group II $(1.11 \pm 0.19 \mathrm{ng} / \mathrm{ml})$, group III $(1.27 \pm 0.20 \mathrm{ng} / \mathrm{ml})$, and group IV $(1.52 \pm 0.21 \mathrm{ng} / \mathrm{ml})$ compared with the control group $(0.61 \pm 0.08 \mathrm{ng} / \mathrm{ml})$. The anti-apoptotic protein; Bcl-2 level was significantly increased in groups II $(485.36 \pm 60.12 \mathrm{U} / \mathrm{ml})$, group III $(361.59 \pm 11.95 \mathrm{U} / \mathrm{ml})$, and group IV $(544.54 \pm 37.11 \mathrm{U} / \mathrm{ml})$ compared with the control group level $(320.61 \pm 7.47 \mathrm{U} / \mathrm{ml})$. Finally for IL-6 level there was a significant increase in group II $(23.13 \pm 1.46 \mathrm{pg} / \mathrm{ml})$, group III $(22.29 \pm 1.48 \mathrm{pg} / \mathrm{ml})$, and group IV $(30.66 \pm 3.20 \mathrm{pg} / \mathrm{ml})$ compared with the control group $(14.74 \pm 1.23 \mathrm{pg} / \mathrm{ml})$.

At 9 months interval, the mean \pm SD of NF- $\mathrm{kB}$ p 65 , Bcl-2 and IL-6 levels were significantly higher in the three groups compared with those obtained in the control group. In addition a significant difference was observed among the three groups, with those of group IV (receiving nitrosamine precursor and infected with E. coli) showing the highest values. Regarding NF-kB p65 levels, there was a significant increase in group II $(1.30 \pm 0.22 \mathrm{ng} / \mathrm{ml})$, group III $(1.66 \pm 0.27 \mathrm{ng} / \mathrm{ml})$, and group IV $(1.72 \pm 0.14 \mathrm{ng} / \mathrm{ml})$ compared with the control group $(0.70 \pm 0.11 \mathrm{ng} / \mathrm{ml})$. The anti-apoptotic protein; Bcl-2 level was significantly increased in groups II $(485.58 \pm 120.36 \mathrm{U} / \mathrm{ml})$, group III $(386.92 \pm 19.14 \mathrm{U} /$ $\mathrm{ml})$, and group IV $(592.60 \pm 75.22 \mathrm{U} / \mathrm{ml})$ compared with the control group level $(323.47 \pm 14.33 \mathrm{U} / \mathrm{ml})$. Finally for IL-6 level there was a significant increase in group II $(26.41 \pm 1.89 \mathrm{pg} / \mathrm{ml})$, group III $(24.37 \pm 1.32 \mathrm{pg} / \mathrm{ml})$, and group IV $(40.55 \pm 2.69 \mathrm{pg} / \mathrm{ml})$ compared with the control group $(15.63 \pm 0.89 \mathrm{pg} / \mathrm{ml})$.

\section{Discussion}

The involvement of bacteria in the process of carcinogenesis remains controversial [6] because of a lack of agreement on potential molecular mechanisms.

It was proven that urinary tract infection promotes carcinogenesis in the urinary tract of the rat and that infection with live E. coli resulted in persistent infection and diffuses urothelial hyperplasia in addition to acute and chronic inflammation [12].

In our study; Group IV (nitrosamine precursor plus $E$. coli group) showed highest incidences of urinary bladder lesions than the nitrosamine precursor group; moreover E. coli group alone was able to produce some histopathological changes in bladder tissue. These findings suggested that urinary bladder infection by $E$. coli may play a major additive and synergistic role in bladder carcinogenesis.

These results are consistent with the study of Ashmawey and colleagues [13] who reported that E. coli infection in the bladder tissues increases the carcinogenic ability of nitrosamine precursors. Three mechanisms were suggested to account for the tumor enhancing effect of $E$. coli in the experiment. First, E. coli infection of bladder tissues increases the carcinogenic ability of nitrosamine precursors and this may be due to increase of nitrite production by the bacteria and continuous production of nitrosoamine by helping in-situ nitrosamine synthesis. Second, E. coli infection accelerated urothelial proliferation. This may have 


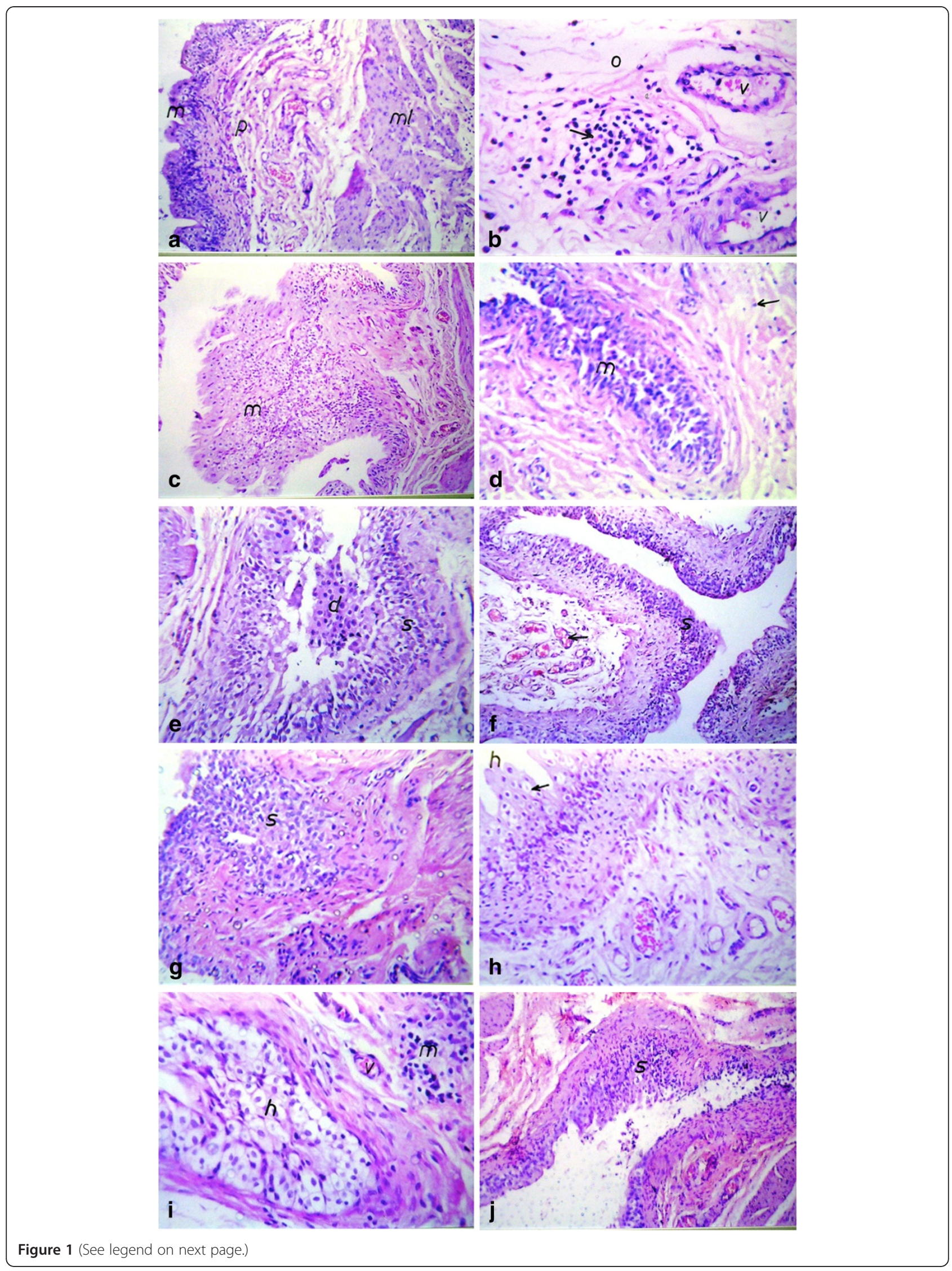




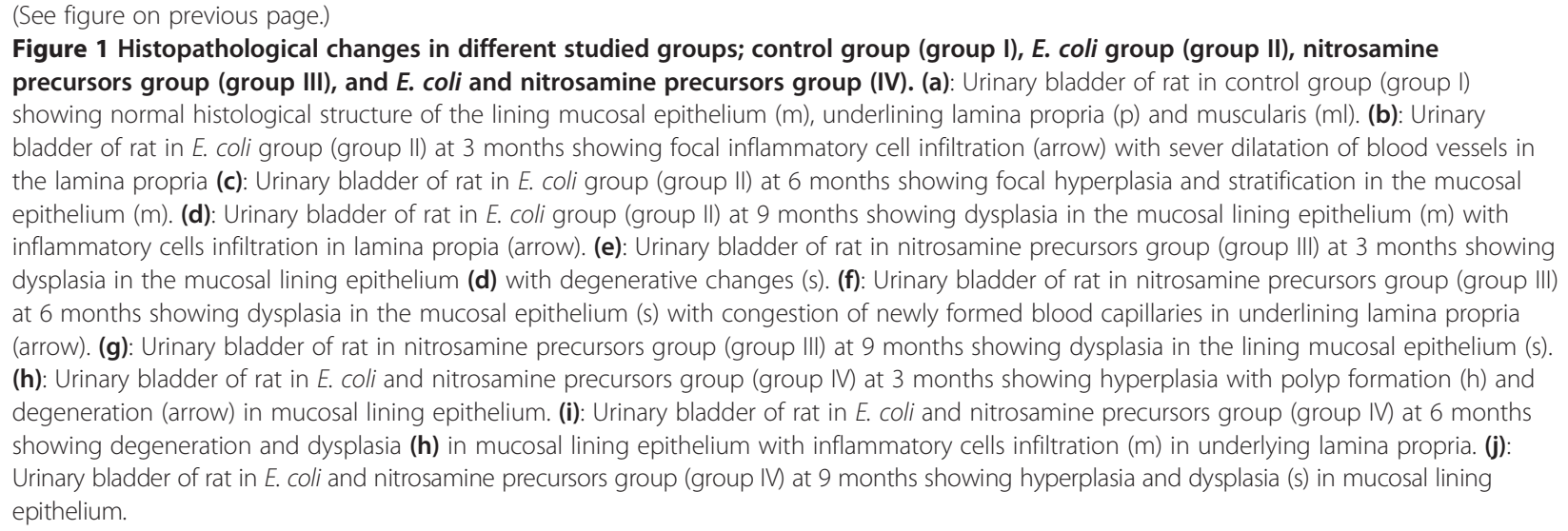

augmented the mutagenic effect of the carcinogen. Third, prolonged oxidative and nitrosative stresses which results in DNA damage and mutation [13].

Our results showed the highest level of NF-kBp65 in $E$. coli plus nitrosamine precursor group. In the absence of inflammatory stimuli, NF- $\mathrm{kB}$ p 65 is retained in an inactive complex in the cytoplasm by the chaperone-like protein inhibitor of Kappa B alpha (I-kB $\alpha)$. With exposure to proinflammatory stimuli, such as Toll-like receptors-4 agonist (TLR4) or pro-inflammatory cytokines, phosphorylation of $\mathrm{I}-\mathrm{kB}$ occurs, leading to its degradation and subsequent release of NF- $\mathrm{kB}$ p65 to translocate to the nucleus, driving inflammatory gene expression [14]. The highest level of NF-kBp65 in E. coli plus nitrosamine precursor group, observed in this study is in agreement with $[15,16]$ who reported that E. coli lipopolysaccharide (LPS), a major cell wall component of $E$. coli, treatment induced IkB phosphorylation, IкB degradation, and NF- $\kappa B$ translocation. Also Saban and colleagues [17] during a study of gene expression changes occurring in the early stages of genitourinary inflammation mediated by LPS reported that NF- $\mathrm{kB}$ pathway genes were up-regulated by LPS stimulation. This can be explained by the fact that induction of inflammation by LPS or E. coli in bladder uroepithelial cells involves the TLRs and CD14. These activate signaling pathways, including NF- $\mathrm{kB}$ and p38 mitogen- activated protein kinase (p38 MAPKs) [18].

Our results showed highest level of Bcl-2 in E. coli plus nitrosamine precursor group followed by $E$. coli group and nitrosamine precursor group respectively. These results can be explained by the ability of bacterial pathogens to inhibit apoptosis in eukaryotic cells during infection as prevention of apoptosis provides a survival advantage because it enables the bacteria to replicate inside host cells [19].

Many pathogens rely on NF- $\mathrm{BB}$ activation to inhibit apoptosis. The Gram-negative bacteria cell surface component LPS activates the NF- $\kappa B$ pathway during infection [20]. Because NF- $k B$ activation has many prosurvival effects on the host cell, activation of the NF- $\mathrm{kB}$ pathway by LPS might be a simple explanation of how most bacteria inhibit apoptosis [19].

The increase in Bcl-2 level in nitrosamine precursor group observed in our results is in consistent with $\mathrm{El}$ Gendy and colleagues [21] who reported that the levels of Bcl-2 protein significantly increased over all the periods of treatment (12 months) in rats receiving nitrosamine precursors compared with the corresponding level of normal control rats fed with standard diet.

Our results showed highest level of IL-6 in E. coli plus nitrosamine precursor group followed by $E$. coli group and nitrosamine precursor group respectively. E. coli enhancing effect on IL-6 production clearly observed in our study is in agreement with Feng and colleagues [15] who reported that LPS treatment caused a marked increase in IL-6 production in macrophages.

Neuhaus and colleagues [22] had also shown that IL-6 and IL-6 receptor expression was found in urothelium, lamina propria and detrusor cells isolated from bladder biopsies of tumor patients; these researchers further found that LPS stimulation evoked a time-dependent synthesis and/or release of IL-6, IL-6 receptor, and transcription factor signal transducer and activator of transcription 3 (Stat3) in cultured human detrusor smooth muscle cells. The ability of E. coli to increase IL-6 level can be explained by activating several signaling pathways, including NF-kB and p38MAPKs [18] with subsequent production of Il-6.

\section{Conclusion}

In conclusion E. coli infection might play a role in the development of bladder cancer and this effect may be mediated by activation of NF- $\mathrm{kB}$ pathway resulting in inhibition of apoptosis and increased inflammation. 
Table 1 NF-kBp65 tissue homogenate level $(\mathrm{ng} / \mathrm{ml})$, serum level of Bcl-2 (U/ml) and IL-6 (pg/ml)

\begin{tabular}{|c|c|c|c|c|c|c|c|c|c|c|}
\hline \multirow[t]{2}{*}{ Group } & & \multicolumn{3}{|c|}{ NF-KBp65 (ng/ml) } & \multicolumn{3}{|c|}{$\mathrm{Bcl}-2$ (U/ml) } & \multicolumn{3}{|c|}{ IL-6 (pg/ml) } \\
\hline & & 3 months & 6 months & 9 months & 3 months & 6 months & 9 months & 3 months & 6 months & 9 months \\
\hline \multirow[t]{2}{*}{ Group I } & Range & $0.51-0.67$ & $0.51-0.75$ & $0.60-0.87$ & 293.30- 331.94 & $310.74-331.94$ & $305.78-348.24$ & $12.65-15.20$ & $13.55-16.95$ & $14.5-17.00$ \\
\hline & Mean $\pm S . D$ & $0.57 \pm 0.07$ & $0.61 \pm 0.08$ & $0.70 \pm 0.11$ & $309.14 \pm 14.55$ & $320.61 \pm 7.47$ & $323.47 \pm 14.33$ & $14.09 \pm 0.87$ & $14.74 \pm 1.23$ & $15.63 \pm 0.89$ \\
\hline \multirow[t]{2}{*}{ Group II } & Range & $0.52-1.13$ & $0.91-1.145$ & $1.13-1.74$ & $329.75-396.42$ & $412.63-584.94$ & $354.27-681.57$ & $17.77-22.44$ & $20.91-25.11$ & $24.76-29.69$ \\
\hline & Mean \pm S.D & $0.92 \pm 0.22^{\mathrm{a}, \mathrm{d}}$ & $1.11 \pm 0.19^{\mathrm{a}, \mathrm{d}}$ & $1.30 \pm 0.22^{a, c, d}$ & $354.74 \pm 23.44^{\mathrm{a}, \mathrm{d}}$ & $485.36 \pm 60.12^{a, c, d}$ & $485.58 \pm 120.36^{a}$ & $19.76 \pm 1.64^{a, d}$ & $23.13 \pm 1.46^{\mathrm{a}, \mathrm{d}}$ & $26.41 \pm 1.89^{\mathrm{a}, \mathrm{d}}$ \\
\hline \multirow[t]{2}{*}{ Group III } & Range & $0.57-1.05$ & $1.02-1.50$ & $1.39-2.09$ & 315.83-351.77 & 341.94-374.09 & $362.57-407.20$ & $17.22-21.78$ & $20.08-24.22$ & $22.50-25.59$ \\
\hline & Mean \pm S.D & $0.84 \pm 0.17^{\mathrm{a}, \mathrm{d}}$ & $1.27 \pm 0.20^{\mathrm{a}, \mathrm{d}}$ & $1.66 \pm 0.27^{\mathrm{a}, \mathrm{b}}$ & $331.78 \pm 11.86^{\mathrm{a}, \mathrm{d}}$ & $361.59 \pm 11.95^{\mathrm{a}, \mathrm{b}, \mathrm{d}}$ & $386.92 \pm 19.14^{\mathrm{a}, \mathrm{d}}$ & $19.21 \pm 1.56^{\mathrm{a}, \mathrm{d}}$ & $22.29 \pm 1.48^{a, d}$ & $24.37 \pm 1.32^{\mathrm{a}, \mathrm{d}}$ \\
\hline \multirow[t]{2}{*}{ Group IV } & Range & $0.94-1.40$ & $1.30-1.87$ & $1.58-1.95$ & $377.06-399.89$ & $484.65-595.49$ & $522.07-726.57$ & $22.00-27.46$ & $26.61-34.78$ & $35.87-43.51$ \\
\hline & Mean $\pm S . D$ & $1.19 \pm 0.19^{a, b, c}$ & $1.52 \pm 0.21^{a, b, c}$ & $1.72 \pm 0.14^{\mathrm{a}, \mathrm{b}}$ & $387.05 \pm 8.40^{a, b, c}$ & $544.54 \pm 37.11^{a, b, c}$ & $592.60 \pm 75.22^{a, c}$ & $24.80 \pm 2.20^{a, b, c}$ & $30.66 \pm 3.20^{a, b, c}$ & $40.55 \pm 2.69^{a, b, c}$ \\
\hline
\end{tabular}

different from $E$. coli group (group II) at $\mathrm{P}<0.05$; c: Significantly different from nitrosamine precursors group (group III) at $\mathrm{P}<0.05$; $\mathrm{d}$ : Significantly different from $E$. coli + nitrosamine precursors group (group IV) at $\mathrm{P}<0.05$. 


\section{Methods}

\section{Experimental animals and dosing}

Ninety five male albino rats, weighing 50-60 gm were included in the study and divided into four groups; as follows: group I (Gr I, 20 rats): Normal control fed the standard diet . Group II (Gr II, 25 rats): E. coli infected; the rats infected by $0.1 \mathrm{ml}$ saline containing suspension of $E$. coli in the bladder (approximately $2 \times 10^{6}$ organisms), according to [23]. Group III (Gr III, 25 rats): Received nitrosamine precursor; dibutyl amine (DBA) $1000 \mathrm{ppm}$ and sodium nitrate $2000 \mathrm{ppm}$; in drinking water according to [21]. Group IV (Gr IV, 25 rats): Received nitrosamine precursor; dibutyl amine (DBA) $1000 \mathrm{ppm}$ and sodium nitrate $2000 \mathrm{ppm}$; in drinking water and infected by $E$. coli in the bladder. At the end of the experiment, animals were decapitated and $5 \mathrm{ml}$ of blood was collected. The present experiment was continued 36 weeks.

\section{Laboratory procedures}

At three months interval (3, 6 and 9 months) animals were sacrificed and bladder tissue was separated and blood was collected into vacutainer clotted tubes. For histopathological studies bladder tissue pieces were fixed in $10 \%$ formalin, blocked in paraffin, sectioned, and stained with hematoxyline and eosin. Finally, the samples were examined by a pathologist.

Specimens of bladder were removed immediately from sacrificed animals, washed with saline, dried, cut into weighed pieces and kept frozen at $-80^{\circ} \mathrm{C}$, then tissue homogenate was prepared according to [24] for NF-kB p65 determination by ELISA kit (Glory Science Co., Ltd, USA) following the manufacturer instructions.

Sera were obtained by centrifugation at $4000 \mathrm{rpm}$ for 10 minutes. Sera were separated. Aliquoted sera were kept frozen at $-80^{\circ} \mathrm{C}$ until used for $\mathrm{Bcl}-2$ determination by ELISA kit (the Calbiochem Laboratories, USA, Cat QIA23) and IL-6 determination by ELISA kit (IBL, USA, Cat IB39452) following the manufacturer instructions.

\section{Statistical analysis}

All statistical analyses were performed using GraphPad Prism version 5.01 software package (GraphPad Software, Inc. CA, USA). Data are presented as mean \pm standard deviation (S.D). To determine differences between groups, analysis of variance (ANOVA) followed by Tukey's multiple comparison post hoc analysis was used for multiple comparisons between different groups. The level of statistical significance was set at probability $\mathrm{P} \leq 0.05$.

\footnotetext{
Abbreviations

E. coli: Escherichia coli; NF-KBp65: Nuclear factor kappa p65; Bcl-2: B-cell lymphoma 2; IL-6: Interleukin 6; UTIs: Urinary tract infections; IL-

$1 \beta$ : Interleukin 1 $\beta$; TNF: Tumor necrosis factor; EGF: Epidermal growth factor; I-kBa: Inhibitor of Kappa B alpha; TLR4: Toll-like receptors-4;
}

LPS: Lipopolysaccharide; CD14: Cluster of differentiation 14; p38 MAPKs: p38 mitogen- activated protein kinase; Stat3: Signal transduction and transcription 3; DBA: Dibutyl amine; S.D: Standard deviation; ANOVA: Analysis of variance.

\section{Competing interests}

The authors declare that they have no competing interests.

\section{Authors' contributions}

HE: Wrote the manuscript and participated in the study design. TS: Revised the manuscript and assisted with data analysis. AS: participated in the study design and supervised the ELISA work. NO: Performed the ELISA work and performed the data analysis. All authors read and approved the final manuscript.

\section{Acknowledgments}

We thank Dr. Heba Fawzy who supervised and assisted in animal handling and dosing and Dr. Adel Bakir who performed the histopathological examination.

\section{Author details}

'Biochemistry Department, Faculty of Pharmacy, Ain Shams University, Cairo, Egypt. 'Biochemistry Department, Faculty of Pharmacy, Al-Azhar University, Cairo, Egypt. ${ }^{3}$ Cancer Biology Department, National Cancer Institute, Cairo University, Cairo, Egypt. ${ }^{4}$ Biochemistry Department, Faculty of Pharmacy, Modern Sciences and Arts University, Cairo, Egypt.

Received: 17 June 2012 Accepted: 30 July 2012

Published: 8 August 2012

\section{References}

1. Beaglehole R, Irwin A, Prentice T: Changing history. The World Health Report 2004, 157:122.

2. El Mawla NG, El Bolkainy MN, Khaled HM: Bladder cancer in Africa: update. Semin Oncol 2001, 28(2):174-178.

3. Abd El Gawad IA, Moussa HS, Nasr MI, El Gemae EH, Masooud AM, Ibrahim IK, El Hifnawy NM: Comparative Study of NMP-22 Telomerase and BTA in the detection of bladder cancer. J Egypt Natl Canc Inst 2005, 17(3): 193-202.

4. Janković S, Radosavljević V: Risk factors of bladder cancer. Tumori 2007, 93:4-12.

5. Pasin E, Josephson DY, Mitra AP, Cote RJ, Stein GP: Superficial Bladder Cancer: An Update on Etiology Molecular Development Classification and Natural History. Rev Urol 2008, 10(1):31-43.

6. Lax AJ, Thomas W: How bacteria could cause cancer: one step at a time. Trends Microbiol 2002, 10(6):293-299.

7. Karin M, Greten FR: NF-KB: linking inflammation and immunity to cancer development and progression. Nature Rev 2005, 5(10):749-759.

8. Shishodia S, Chaturvedi MM, Aggarwal BB: Role of Curcumin in Cancer Therapy. Curr Probl Cancer 2007, 31(4):243-305.

9. Pacifico F, Leonardi A: NF-KB in solid tumors. Biochem Pharmacol 2006, 72:1142-1152

10. Rose-John S, Schooltink H: Cytokines are a therapeutic target for the prevention of inflammation-induced cancers. Recent Results Cancer Res 2007, 174:57-66.

11. Andrews B, Shariat SF, Kim JH, Wheeler TM, Slawin KM, Lerner SP: Preoperative plasma levels of interleukin- 6 and its soluble receptor predict disease recurrence and survival of patients with bladder cancer. J Urol 2002, 167:1475-1481.

12. Schetter AJ, Heegaard NH, Harris CC: Inflammation and cancer: interweaving microRNA free radical cytokine and p53 pathways. Carcinogenesis 2010, 31:37-49.

13. Ashmawey AM, Mohamed WS, Abdel-Salam IM, El-Gendy SM, Ali Al, El-Aaser AA: Role of urinary tract bacterial infection in the process of bladder carcinogenesis (molecular and biochemical studies). AJMS 2011, 2:31-40.

14. Kawai T, Akira S: Signaling to NF-kB by Toll-like receptors. Trends Mol Med 2007, 13:460-469.

15. Feng D, Ling W, Duan R: Lycopene suppresses LPS-induced NO and IL-6 production by inhibiting the activation of ERK P38MAPK and NF-KB in macrophages. Inflamm Res 2010, 59:115-121. 
16. Hsieh N, Chang AS, Teng C, Chen C, Yang C: Aciculatin inhibits lipopolysaccharide-mediated inducible nitric oxide synthase and cyclooxygenase-2 expression via suppressing NF-KB and JNK/p38 MAPK activation pathways. J Biomed Sci 2011, 18:28.

17. Saban MR, Hellmich H, Nguyen N, Winston J, Hammond TG, Saban R: Time course of LPS-induced gene expression in a mouse model of genitourinary inflammation. Physiol Genomics 2001, 5:147-160.

18. Schilling JD, Martin SM, Hunstad DA, Patel KP, Mulvey MA, Justice SS, Lorenz RG, Hultgren SJ: CD14- and Toll-like receptor-dependent activation of bladder epithelial cells by lipopolysaccharide and type 1 piliated Escherichia coli. Infect Immun 2003, 71:1470-1480.

19. Faherty CS, Maurelli AT: Staying alive: bacterial inhibition of apoptosis during infection. Trends Microbiol 2008, 16:173-180.

20. Palsson-McDermott EW, O'Neill LAJ: Signal transduction by the lipopolysaccharide receptor Toll-like receptor-4. Immunology 2004, 133(2):153-162.

21. El Gendy S, Hessien M, Abdel Salam I, Morad M, EL-Magraby K, Ibrahim HA Kalifa MH, El-Aaser AA: Evaluation of the possible antioxidant effects of Soybean and Nigella Sativa during experimental hepatocarcinogenesis by nitrosamine Precursors. Turk J Biochem 2007, 32(1):5-11.

22. Neuhaus J, Schlichting N, Oberbach A, Stolzenburg JU: Lipopolysaccharidemediated regulation of interleukin-6 in cultured human detrusor smooth muscle cells. Urologe A 2007, 46:1193-1197.

23. Higgy NA, Verma AK, Erturk E, Bryan GT: Augmentation of N-butyl-N-(4hydroxybutyl)nitrosamine (BBN) bladder carcinogenesis in Fischer 344 female rats by urinary tract infection. Proc Amer Assoc Cancer Res 1885, 26:118-124

24. Tripathi DN, Jena GB: Effect of melatonin on the expression of Nrf2 and NF-KB during cyclophosphamide-induced urinary bladder injury in rat. J Pineal Res 2010, 48:324-331.

doi:10.1186/1750-9378-7-19

Cite this article as: El-Mosalamy et al:: Role of chronic E. coli infection in the process of bladder cancer- an experimental study. Infectious Agents and Cancer 2012 7:19.

\section{Submit your next manuscript to BioMed Central and take full advantage of:}

- Convenient online submission

- Thorough peer review

- No space constraints or color figure charges

- Immediate publication on acceptance

- Inclusion in PubMed, CAS, Scopus and Google Scholar

- Research which is freely available for redistribution 